\title{
Gerakan Samin: Perlawanan ... Rakyat Tanpa Kekerasan
}

\author{
A. Widyarsono
}

erakan Samin adalah gerakan perlawanan kaum tani di tanah Jawa berdasarkan ajaran Surontiko Samin, seorang petani dari desa Ploso Kediren, Randublatung, Blora. Gerakan ini mendapat perhatian besar dari pemerintah Kolonial Belanda terutama pada tahun 1905-1930. Para pamoing desa dan pejabat-pejabat pemerintah lainnya sangat jengkel dengan cara-cara orang Samin menolak pajak, politik etis, kerja.pasa, dan aturan-arutan negara lainnya. Namun sekaligus gerakan samin juga merupakan suatu fenomena unik dalam sejarah gerakan petani di tanah Jawa. Ini nampak dari sebutan-sebutan yang diberikan oleh para peneliti pada zaman itu, misalnya "Komunisme awal yang utopis," teori sosial yang bisa menjadi matang dalam kepala orang desa Jawa" (S. Hurgronje), dan "komunisme yang mengungkapkan penolakan terhadap kekuasan negara, milik pribadi, institusi-institusi kaum borjuis seperti pernikahan, dan lain-lain" (Tjipto Mangoenkoesoemo). ${ }^{1}$

- Penelitian tentang Gerakan Samin sendiri telah dimulai oleh pemerintah kolonial Belanda. Ada sebuah laporan resmi yang komprehensif yang dibuat oleh. Asisten
Residen Tubun, J.E. Jasper pada tahun 1917. ${ }^{2}$ Selain itu ada sebuah tulisan tidak resmi yang dibuat oleh seorang tokoh pergerakan Nasional. Tjipto Mangoenkoesoemo pada tahun $1918 .{ }^{3}$ Pada masa setelah revolusi Bolshevik itu Tjipto tertarik untuk menggambarkan persamaan antara agama Adam yang diajarkan Surontiko Samin dengan sebuah sekte agama di Rusia pada zaman tsar yang meniadakan makhluk-makhluk illahi, kekuatan tsar, milik dan hukum. ${ }^{4}$ Gerakan Samin kembali-menjadi bahan penelitian yang menarik sejak tahun $1960-$ an seperti yang dilakukan oleh Ongokham, The Șiauw Giap, Harry J. Benda dan L.

"Lih. Sindhunata, "Die Samin Bewegung" (1992), hal. 175.

${ }^{2}$ Verslag betreffende het onderzoek in zake de Saminbeweging ingesteld ingevolge het Gouvernements bestuit van 1 Juni 1917, No. 20 (Batavia, 1918). Tulisan ini biasanya dikenal oleh para peneliti gerakan Samin selanjutya sebagai Laporan Jasper.

${ }^{3}$ Tjipto Mangoenkoesoemo, Het Saminisme: Rapport uitgebracht aan de Vereeniging "Insulinde" (Semarang, 1918).

${ }^{4} B d k$. Shiraisi, T., Zaman Bergerak (1997); hal. 126. 
Topik: Gerakan Samin: Perlawanan Rakyat Tanpa Kekerasan, A. Widyarsono

Castles, Victor T. King, Pieter E. Korver Paulus Widyanto, Suripan Sadi Hutomo, dan Sindhunata. ${ }^{5}$

Salah satu hal yang menonjol dari Gerakan Samin adalah cirinya sebagai gerakan perlawanan rakyat tanpa kekerasan. Tulisan berikut ini berusaha menjelaskan bagaimana bentuk-bentuk perlawanan tanpa kekerasan yang dilaksanakan gerakan Samin dalam rentang waktu dari tahun 1905 s.d. 1930. Namun sebelumnya akan dijelaskan terlebih dahulu tentang asal-usul dan perkembangan gerakan Samin. Selanjutnya akan diuraikan mengenai faktor-faktor penyebab munculnya gerakan perlawanan tanpa kekerasan dari kaum Samin tersebut. Selain faktor-faktor moral ekonomi -dan moral politik, nampaknya peranan keyakinan orang Samin yang terungkap dalam agama Adam tidak bisa diabaikan. Itulah sebabnya akan dijelaskan juga mengenai keyakinan orang Samin tersebut. Akhirnya, tulisan ini ditutup dengan suatu refleksi singkat mengenai apa yang bisa kita pelajari dari gerakan Samin.

\section{Asal-mula dan Perkembangan Gerakan Samin ${ }^{6}$}

Gerakan Samin bertitik tolak dari Surontiko Samin. Dia lahir di desa Ploso Kediren, Randublatung, Blora, pada tahun 1859 sebagai anak kedua dari lima bersaudara (laki-laki semua). Itulah sebabnya Samin diindentifikasikan oleh para pengikutnya sebagai Bima (atau Werkudara), yang kedua dari Pandawa. Samin dianggap memiliki sifat-sifat seperti Werkudara: tidak sopan dan kasar, namun dalam hatinya jujur, murah hati, luhur dan sabar. Samin adalah seorang petani gogol atau sikep yang memiliki sawah seluas 3 bau $^{8}$; ladang 1 bau, dan 6 ekór sapi. Maka dia tidak tergolong petani miskin. ${ }^{9}$
Ada sebuah cerita mistis mengenai bagaimana Samin menjadi guru ilmu Samin. Pada suatu hari Samin pergi bertapa ke sebuah gunung. Dia memohon kepada Yang Maha Kuasa berkat bagi manusia. Pada saat dia masuk dalam meditasi yang mendalam, jatuhlah sebuah buku dari langit. Buku itu berisi ilmu bagi keselamatan manusia. Meskipun Samin buta huruf, namun dia dapat membaca buku itu dan dengan patuh semangat mendalaminya. ${ }^{10}$

5Ongokham, Saminisme: Tinjauan social
ekonomi dan kebudayaan pada gerakan tani
pada awal abad keXX". (Jakarta, 1964, manu-
skrip yang tidak diterbitkan), The Siauw Giap,
"The Samin and Samat Movements in Java.
Two examples of Peasant Resistane" dalam
Joumal of South-East Asia and Far-East, No.
2 (1967), hal. 303-310 dn No. 1 (1968), hal.
107-113, dan "The Samin Movement in Java. Complementary Remarks", dalam: lbid., No. 1 (1969), hal. 63-77). Sedangkan hasil-hasil penelitian lain tentang Gerakan Samin silakan lihat dalam Daftar Pustaka karangan ini.

${ }^{6}$ Bagian ini diringkas dari: Benda/Castles.. "The Samin Movement" (1969), hal. 210-219; Widiyanto, P., "Samin Surontiko dan Konteksnya" (1983), hal. 60-62; Sadi Hutomo, S., "Samin Surontiko dan Ajaran-ajarannya" (1985), hal. 3-6 Sindhunata, "Die Samin Bewegung" (1992), hal. 175-179).

${ }^{7} \mathrm{Gogol}$ adalah petani yang memiliki rumah dan tanah sendiri, memiliki bagian dari tanah komunitas desa, dan oleh karena itu wajib membayar pajak dan melakukan kerja paksa. Sikep dan kuli kenceng memiliki status yang sama dengan gogol. (Bdk. Shiraishi, T., "Dangir's Testimony" (1990), hal. 111).

81 bau sama dengan 0,7 hektar (Shiraishi, T.., (1997), hal. 12.

9Bdk. Benda/Castles (1969), hal. 210-211; Widiyanto (1983), hal. 60; Sadi Hutomo, S. (1985), hal. 4; Shindunata (1992), hal. 175176.

${ }^{10} \mathrm{Bdk}$. Sindhunata (1992), hal. 176. 
Sekitar tahun 1890 Samin mulai mengajarkan ilmunya kepada orang-orang sedesanya dan desa-desa sekitarnya. Mulamula pemerintah kolonial Belanda tidak tertarik dengan ajaran Samin, karena dianggap sebagai ajaran kebatinan atau agama baru yang tidak menganggu keamanan. $\mathrm{Na}$ mun hal ini berubah sejak tahun 1905, yakni ketika para pengikut Samin mulai menarik diri dari kehidupan umum desanya, menolak memberikan sumbangan bagi lumbung desa, dan menolak mengandangkan ternak mereka di kandang umum. Mereka masih mau membayar pajak, namun tidak sebagài kewajiban, melainkan sebagai sumbangan sukarela. Surontiko Samin sendiri menghentikan pembayaran pajak. Meskipun begitu dia tidak mengajurkan para pengikutnya berbuat yang sama, karena mereka dianggapnya belum "bersih" untuk berbuat demikian."

Pada bulan Januari 1903 dilaporkan oleh Residen Rembang bahwa di Blora dan Bojonegoro terdapat 772 orang Samin yang tersebar di 34 desa. Penduduk desa dari Ngawi dan Grobogan yang berbatasan dengan Blora juga datang untuk mempelajari ajaran Samin. Pada tahun 1906 pengikut Samin juga berkembang di sebelah selatan. kabupaten Rembang. Setahun kemudian dilaporkan bahwa pengikut samin telah mencapai 3.000 orang..$^{12}$

Pada tahun 1907 muncullah isu bahwa pada tanggal 1 Maret, kaum Samin merencakan pemberontakan. Residen Rembang tidak terlalú serius menanggapi hal itu, karena biasanya pemberontakan Samin tanpa kekerasan dan gampang dipadamkan. namun Kontrolir Blora ${ }^{13}$ menganggap serius isu tersebut. Pada saat orang Samin di desa kedung Tuban sedang mengadakan selamatan, polisi menangkapi kaum Samin yang datáng dengan alasan bahwa mereka sedang menyiapkan pemberontakan. Orangorang Samin itu tidak mengadakan perla- wanan apa-apa. Surontiko Samin sendiri pada saat itu tidak hadir. Namun beberapa hari kemudian dia diundang oleh Bupati Rembang dan ditangkap. Setelah diinterogasi dia bersama beberapa pengikutnya dibuang keluar Jawa. Pada tangal 2 September 1914, ia meninggalkan Kota Tengah, - Padang. ${ }^{14}$

Ditangkapnya Surontiko Samin tidak. mematikan gerakan Samin. Pada tahun 1908 Wongsorejo giat menyebarkan ajaran Samin di Jawa, dekat Madiun. Segera dia ditangkap dan dibuang bersama dua orang kawannya. Dia mengaku telah mengajarkan untuk tidak membayar pajak dan menolak kerja rodi. Selanjutnya pada tahun 1911 Surohidin, menantu Surontiko Samin dan Pak Engkrak, muridnya menyebarkan ajaran Samin di daerah Kabupaten Grobogan, sementera Karsiyah, murid Surontiko Samin yang lain menyebarkan di Kajen, Pati. ${ }^{15}$

Gerakan Samin ini mencapai puncaknya pada tahun 1914, mungkin karena pajak yang dinaikkan oleh pemerintah. Di Grobogan kaum Samin tidak mau lagi menghormati pemerintah. Tindakan ini bahkan mendapat dukungan dari beberapa aparat desa. Pada saat yang sama di Balerejo,

"Bdk. Benda/Castles (1969), hal. 211; Widiyanto (1983), hal. 60; Sadi Hutomo, S. (1985), hal. 4; Sindhunata (1992), hal. 178.

${ }^{12} /$ bid.

${ }^{13}$ Hirarkhi administrasi Belanda saat itu dari atas adalah: Gubernur Jendral, Residen, Asisten Rsiden dan Kontrolir, sementara birokrasi pribumi mulia dari Bupati pribumi mulai Bupati, Patih, Wedana, dan Asisten Wedana (Shirasihi, T. (1990), hal. 107).

${ }^{14} \mathrm{Bdk}$. Benda/Castles (1969), hal. 211212; Widiyanto (1983), hal. 60; Sadi Hutomo, s. (1985), hal. 5; Sindhunata (1992); hal. 178179.

${ }^{15}$ Bdk. - Benda/Castles (1969), hal. 212, 213; Widiyanto (1983), hal. 61; Sadi Hutomo, S. (1985), hal. 5. 
Topik: Gerakan Samin: Perlawanan Rakyat Tanpa Kekerasan, A. Widyarsono

Madiun, seorang Samin bernama Projodikoro menyatakan kepada para pengikutnya bahwa pajak akan naik terus dan menyarankan mereka untuk menipu aparat pemerintah supaya tidak membayar pajak. Sementara itu di Kajen, Pati, Karsiyah tampil sebagai Pangeran Sendang Janur dan mempengaruhi penduduk Pati agar tidak membayar pajak.

$\mathrm{Hal}$ yang sama juga terjadi di desa Tapelan, Bojonegoro yang sejak tahun 1890 terdapat pengikut Samin. Sejak tahun 1912 mereka menyewa tanah desa di tepi Bengawan Solo. Namun pada tahun 1914 mereka menolak membayar pajak, karena menurut mereka tanah itu milik para penggarap dan mereka "tahu hak-hiak mereka". Mereka berani mengancam Asisten Wedana. Akan tetapi kemudian mereka ditangkap dan dipenjara. ${ }^{16}$

Insiden-insiden di atas terjadi beisamaan dengan meluasnya gerakan Sarekat Islam di seluruh Jawa. Itulah sebabnya gerakan Samin pada saat itu mendapat perhatian besar. Ada debat publik yang mempertanyakan apakah gerakan itu berbahaya atau tidak. Bahkan sempat muncul pula beberapa kesalahan dari pihak pemerintah dalam menilai gerakan itu. Misalnya, ketika terjadi protes para petani penyewa di tanah swasta pada tahun 1916 di dekat Surabaya dan di Tuban, mereka dikira sebagai pengikut Samin. Padahal mereka bukan orang Samin. Selain itu ada pula isu tanpa dasar bahwa kaum Samin dan pengikut Sarekat Islam bersama-sama mencanangkan perang salib melawan pëmerintah. Dalam situasi seperti inilah pada tahun 1917, Asisten Resideri Tuban, J.E. Jasper diminta oleh Departemen Dalam negeri (Binnenlads Bestuur) untuk menyelidiki latar belakang ekonomis gerakan Samin. Laporan Jasper inilah yang biasanya menjadi materi utama tulisan-tulisan mengenai Gerakan Samin selanjutnya. ${ }^{7}$
Walaupun terjadi beberapa perluasan di daerah baru seperti di Undaan, Kudus pada tahun 1916, namun jumlah pengikut Samin pada saat itu mulai menurun. Jasper melaporkan bahwa pada tahun 1917 terdapat 2.305 keluarga Samin, termasuk 1.701 di kabupaten Blora, 283 di Bojonegoro, dan sisanya di Pati, Rembang, Grobogan, Ngawi, dan Kudus. ${ }^{18}$

Sebenarnya Gerakan Samin bukanlah gerakan yang homogen, karena ada beberapa model perlawanan tanpa kekerasan yang dijalankan oleh masing-masing kelompok. ${ }^{19}$ Salah satu varian dari gerakan ini yang punya pengaruh pada masa selanjutnya adalah gerakan yang dipimpin oleh Samat, seorang petani dari Pati antara tahun 1914 s.d. $1920 .{ }^{20}$ Para pengikut Samat yakin bahwa tanah hanya digajikan kepada orang Belanda. Pada saat tanah itu dikembalikan kepada penduduk asli (sekitar tahun 1930), Ratu Adil sebagai Raja Kembar akan datang dari Timur dan Barat, dan akan mendirikan sebuah kerajaan berdasarkan persamaan (sama rasa sama rata). ${ }^{21}$

Pada tahun 1920-an laporan-laporan pemerintah kolonial menyebut Gerakan Samin sebagai suatu gangguan kecil. Laporan-

${ }^{16} \mathrm{Bdk}$. Benda/Castles (1965), hal. 213; Widiyanto (1983), hal. 61; Sadi Hutomo, S. (1985), hal. 5.

${ }^{17}$ Bdk. Benda/Castles (1969), hal. 213214.

${ }^{18} \mathrm{Bdk}$. Ibid.

${ }^{19}$ Model-model perlawanan ini akan dibahas dalam bagian selanjutnya tulisan ini.

${ }^{20}$ Pengaruh gerakan Samat ini misalnya nampak dalam kesaksian yang dibuat yang dibuat oleh Dangir, seorang pengikut samin dari desa Genengmulyo, Pati. Naskah "Dangir's Testimony" ini menjadi titik tolak penelitian $T$. Shiraishi untuk merefleksikan kembali Saminisme (lih. Shiraishi, T. (1990), hal. 95-120).

${ }^{21} \mathrm{Bdk}$. Benda/Castles (1969), hal. 215. 
laporan itu juga menunjukkan data-data perkembangan atau lebih sering penurunan jumlah pengikutnya. Detail-detail semacam itu justru diberikan di luar kabupaten Blora, mungkin karena di Blora sendiri pengetahuan tentang gerakan ini dianggap mencukupi dan gerakannya sendiri sudah tidak tumbuh lagi. Sejak tahun 1930 tidak ada. pemberitaan lagi mengenai orang Samin. Baru pada tahun 1950-an muncul lagi tulisantulisan resmi tentang mereka dari pemerintah Republik Indonesia. ${ }^{22}$

\section{Perlawanan Tanpa Kekerasan dalam Gerakan Samin}

Protes atau perlawanan yang dilakukan oleh Gerakan Samin biasanya dalam laporan resmi pemerintah kolonial dikategorikan sebagai lijdelijk verzet, artinya sebagai protes yang sabar dan tenang, sebagai perlawanan tanpa kekerasan. Itulah sebabnya menurut S. Hurgronje, protes mereka dibandingkan dengan protes-protes kaum tani lainnya merupakan protes yang paling tidak berbahaya. ${ }^{23}$ Maka dalam bagian ini akan diuraikan beberapa model perlawanan tanpa kekerasan yang dilakukan oleh kaum Samin tersebut.

Salah satu model perlawanan kaum Samin yang terkenal adalah boikot terhadap pajak. Ada sebuah ilustrasi menarik menganai hal ini yang diberikan oleh seorang wartawan Jawa pada bulan Desember 1914, ketika seorang Samin diperiksa oleh seorang Patih dalam pengadilan. ${ }^{24}$

"Kamu masih hutang 90 sen kepada negara" "Saya tak hutang kepada negara"

"Tapi kamu mesti bayar pajak"

"Wong Sikep (yakni, orang Samin) tak kenal pajak".

Jawaban ini menurut patih terlalu berani, dan dia pun memerintahkan kepada polisi yang duduk di dekat orang Samin itu untuk menampar mukanya. Pengikut Samin itu tetap tenang, dan ketika dia sudah menerima tamparan itu, dia berkata, "Tentu saja priyayi ini tersinggung, dan menganggap saya menjengkelkan. Negara memerintahkannya mengumpulkan pajak, sedangkan saya tak mau membayarnya. Tentu saja dia jadi jengkel."

"Apa kamu gila atau pura-pura gila?

"Saya tidak gila, dan juga tidak pura-pura gila? "Kamu biasanya bayar pajak, mengapa sekarang tidak?"

"Dulu itu dulu, sekarang itu sekarang. Mengapa negara tak habis-habisnya minta uang?"

"Negara mengeluarkan uang juga untuk penduduk pribumi. Kalau negara tak punya cukup uang, tak mungkin merawat jalan dengan baik". "Kalau menurut kami keadaan jalan-jalan itu tidak baik, kami akan membetulkannya sendiri."

"Jadi kamu tak mau bayar pajak?"

"Wong Sikep tak kenal pajak"

Orang semacam itu biasanya sulit dianjurkan untuk punya pendapat lain. Maka keputusan Pengadilan Distrik berbunyi demikian, "Pengadilan Distrik memerintahkan kamu untuk membayar hutangmu kepada negara. Jika kamu tidak membayarnya dalam 8 hari .... barang-barangmu akan disita. Pergilah!" Dan sang orang Samin itu pergi dengan tenang dan berkata, "Setahu saya, saya tidak meminjam apa-apa dari negara." Ketika waktu 8 hari itu lewat dan dia tetap menolak untuk membayar, barang-barangnya disita ... Tidak ada dari mereka yang menghalangi penyitaan itu ... Pada tanggal 8 dan 9 Januari barangbarang itu dijual. Uang hasil penjualan dipakai untuk membayar pajak dan sisanya dikembalikan kepada pemiliknya. Namun dia tidak menerimanya. Katanya, "Setahu saya, saya tidak menjual apa-apa ..."

Membaca ilustrasi di atas nampak bahwa kaum Samin menolak pajak dengan mengatakan. "Wong Sikep tak kenal pajak." Pajak merupakan sesuatu yang asing bagi mereka. Orang tua dan simbah-simbah mereka tidak mengenal hal itu. Mereka bahkan

\section{${ }^{22}$ Bdk. Ibid., hal: 215-219.}

${ }^{23} \mathrm{Bdk}$. Sindhunata (1992), hal. 187.

${ }^{24}$ Benda/Castles (1969), hal. 225; Widiyanto (1983), hal. 66; Shiaishi (1990), hal. 118-119, dikutip dari De'Goeroe IImu Samin", De Indische Gids, 1915, 1, hal 535-6. Artikel ini sebelumnya dimuat dalam surat kabar De Locomotief, Semarang. 
yakin bahwa penarik pajak adalah orang jahat. Ketika ditanya mengapa dulu mereka biasanya membayar pajak, dengan ringan mereka menjawab, "Dulu itu dulu, sekarang itu sekarang". Bisa dibayangkan bentuk perlawanan seperti ini membuat marah dan jangkel pegawai pemerintah yang harus menarik pajak dari mereka. Namun anehnya kaum Samin tetap melayani mereka, walaupun akhirnya barang-barang mereka habis disita negara. Meréka tidak memprotesnya, karena mereka percaya bahwa suatu saat nanti barang-barang itu akan menjadi milik mereka kembali. Ketika sisa uang penjualan barang-barang sitaan itu hendak dikembalikan kepada mereka, mereka tidak mau menerimanya dengan alasan, "Saya tidak menjual apa-apa" Menghadapi tindakan kaum Samin seperti itu para pegawai pemerintah kebingungan untuk menanggapinya. Pajak harus dibayar dengan uang, namun kaum Samin menolaknya dan berkata, "Tapi apa itu uang? Saya tidak dapat berbuat apa-apa dengan uang"25

Tidak semua kelompok Samin menolak menyerahkan uang kepada pemerintah. Namun pembayaran semacam itu tidak mereka lihat sebagai pelunasan pajak, melainkan sebagai zakat fitrah. Maka mereka tidak mengenal paksaan dan kewajiban untuk membayar pajak. Menyerahkan uang atau tidak kepada negara lebih merupakan keputusan bebas mereka. Dengan demikian pajak dipahami sebagai sumbangan sukarela dan oleh karena itu penarik pajak mereka pandang sebagai pengemis. Di daerah Bojonegoro para pegawai pemerintah menarik pajak dengan baik, karena mereka meminta uang kepada kaum Samin seperti pengemis. ${ }^{26}$

Memang perlawanan kaum Samin terutama ditujukan pada institusi pajak. ${ }^{27} \mathrm{Na}-$ mun berikut ini akan ditunjukkan bahwa protes kaum Samin yang unik itu juga ditujukan pada lembaga-lembaga dan per- aturan-peraturan desa lainnya. ${ }^{28}$

Kaum Samin menolak untuk melaksanakan kewajiban-kewajiban desa. Misalnya, mereka tidak mau ikut serta dalam tugas jaga malam, karena mereka merasa tidak bertanggungjawab untuk hal ini. Sebagai alasan mereka menjelaskan bahwa pada malam hari mereka telah sibuk untuk menjaga istri dan anak-anak mereka. Seandainya mereka melaksanakan salah satu tugas dari desa, mereka memandangnya tidak sebagai pelaksanaan kewajiban, me: lainkan sebagai sambatan (kerja suka-rela). Menurut kaum Samin, desa tidak memiliki hak untuk memaksa tugas apapun kepada mereka.

Seandainya mereka tidak bisa menghindari tugas yang diberikan desa, maka mereka mengungkapkan protes dengan tingkah laku provokatif yang absurd. Misalnya, kalau seorang aparat desa mengharuskan setiap penduduk untuk mengirim watu (batu besar) untuk membuat jalan batu, mereka mengirim kerikil dan menerangkan bahwa kerikil juga termasuk batu. Selain itu diberitakan juga bahwa beberapa kaum Samin meletakkan 2 atau 3 kerikil di depan rumah mereka atau di tempattempat yang tidak berarti (mis. di selokan) . agar perintah terpenuhi. Di lain pihak, juga terjadi bahwa mereka melaksanakan tugasnya tanpa istirahat dan makan sehingga harus diperintah supaya menghentikan pekerjaannya. Pegawai-pegawai pemerintah kembali kebingungan menghadapi tindakan

${ }^{25}$ Sindhunata (1992), hal. 179, 184.

${ }^{26}$ Bdk. Ibid., hal. 184-185.

${ }^{27}$ Mengenai alasan-alasan yang menyebabkan perlawanan terhadap institusi pajak masih akan dijelaskan dalam bagian selanjutnya.

${ }^{28}$ Bagian ini terutama diambil dari: Sindhunata (1992), hal. 185-187. 
kaum Samin yang berada di luar perhitungan mereka. Sebaliknya, kaum Samin merasa hal itu sebagai sesuatu yang wajar, karena bukanlah mereka harus membuat para penguasa menjadi tenang.

Cara perlawanan lain yang digunakan kaum Samin adalah kesalahpahaman yang disengaja terhadap perintah-perintah. Misalnya, jika seorang Samin diperintah untuk memelihara suatu bagian jalan ("duwek$m u^{\prime \prime}$ ), maka dapat saja terjadi bahwa dia memagarinya dengan bambu dan berpurapura mengikuti perintah penguasa, bahwa bagian ini duwekmu. Duwekmu memiliki dua arti, yakni: "milikmu" atau bagianmu" (artinya, "tanggung jawabmu"). Tentu saja yang dimaksud oleh penguasa adalah arti yang kedua, yakni bahwa seseorang seharusnya memelihara bagian yang ditugaskan baginya. Sedangkan si orang Samin itu menginterpretasikan perintah itu menurut artinya yang pertama (milikku) dan akibatnya memprotes, jika seseorang melompati pagarnya.

Di samping perlawanan langsung, ada juga tingkah laku yang mengungkapkan tuntutan-tuntutan tertentu. Misalnya, tanpa malu-malu kaum Samin mengambil kayu untuk kebutuhan mereka dari hutan, meskipun secara hukum mereka dianggap mencuri. Akan tetapi mereka merasa tidak bersalah dan mengingkari bahwa telah mencuri, karena bukankah mereka mengambil dari hutan alamiah yang tidak dimiliki siapapun. Alasan mereka itu bukan tanpa dasar. Pemerintah memang mengadakan pembedaan antara "opslag cultur", artinya hutan primer alamiah dan "nieuwe culturu", artinya hutan yang ditanami pemerintah. "Seandainya saya mengambil kayu dari hutan yang ditanami pemerintah, maka saya mencuri. Tetapi saya tidak mengambil kayu dari hutan yang ditanami pemerintah, maka saya juga tidak mencuri apa-apa, "kata kaum Samin dan mereka merasa tidak bersalah.

Yang mengagumkan dari segala model perlawanan tanpa kekerasan yang dilakukan oleh kaum Samin tersebut adalah kesabaran mereka. Sering kali pejabat desa atau polisi desa kehilangan kesabaran mereka, karena kaum Samin memiliki kesabaran yang luar biasa. Kaum Samin tidak mengeluh dan membiarkan para pejabat pemerintah melakukan apa saja, termasuk kalau mereka mengambil harta milik mereka. Orang-orang Samin itu memilih diam saja atau bertingkah laku seolah-olah mereka tidak mengerti apa-apa, ketika polisi menanyai mereka. Kalau mereka suatu saat harus berbicara, maka jawabannya pasti membuat merah muka para pejabat itu. Dalam penjara mereka bertingkah laku yang berbeda dengan para tahanan lainnya. Mereka tidak membuat masalah dengan para penjaga dan menanggung hukuman mereka dengan kesabaran yang luar biasa. Dalam diri mereka nampak bahwa jiwa ilmu Samin, yakni nglakoni sabar (bertingkah laku sabar) masih hidup.

\section{Mengapa Rakyat Samin Melawan Negara?}

Telah dikatakan di atas bahwa perlawanan kaum Samin terhadap negara terutama ditujukan pada institusi pajak. Mengapa mereka menolak membayar pajak? Masalah pajak dirasakan makin memberatkan justru ketika politik etis dilaksanakan di Rembang, Madiun, dan Semarang. Sebenarnya politik etis bertujuan untuk memperbaiki kemakmuran rakyat yang dilaksanakan dengan beberapa cara seperti: sapi lokal dalam peternakan rakyat diganti dengan sapi Bengala, sistem irigasi pertanian diperbaiki, diadakan kas desa dengan dana melalui sawah celengan (sawah untuk kas desa), dan dimungkinkan menebus kerja bakti untuk desa. Ironisnya, tujuan yang baik 
itu justru menambah beban ekonomis bagi rakyat, karena biaya untuk semua lembaga baru itu ditarik dari rakyat. Akibatnya, muncul pungutan-pungutan baru yang memberatkan rakyat desa. ${ }^{29}$

Selain itu pembaharuan pajak tanah yang diterapkan pada tahun 1913 - 1914 justru mengakibatkan beban pajak yang bertambah berat bagi petani. Aturan pajak baru itu berlaku bagi para petani yang memiliki tanah yang lebih dari $1 / 4 \mathrm{bau}$. Ini berati bahwa mereka yang hanya memiliki pekarangan pun tiba-tiba terkena pajak. Seorang pemimpin kaum Samin dari Kediren, Blora yang bernama Jokromi mengeluh bahwa pajak tanah naik terus. Kenaikan pajak ini tidak hanya berlaku di Blora, namun juga di daerah-daerah kaum Samin yang lain. Towongso, seorang Samin dari Simo, Grobogan menyebutkan bahwa pajak tanah untuk sawah naik menjadi 4,40 Gulden per bau. Ini merupakan kenaikan yang tinggi, karena sebelumnya harga 1,50 Gulden per bau. ${ }^{30}$

Bagi penduduk desa pajak itu menjadi makin berat, karena penarikannya sudah dilakukan pada masa sebelum musim panen, saat petani mengerjakan sawahnya untuk menjamin pendapatan keluarganya. Padahal baru setelah musim panen mereka dapat memperoleh uang, misalnya dengan bekerja di perkebunan, agar dapat membayar pajak. ${ }^{31}$

Selain pajak dan pengeluaran-pengeluaran yang disebut di atas; para petani juga harus mengeluarkan uang mereka untuk hal-hal seperti sanitasi rumah untuk melawan penyakit pes, pembangunan sekolah desa dan balai desa, pembentukan tamtama (satuan kemanan desa), dan bea untuk pernikahan dan perceraian. ${ }^{32}$

Dari penjelasan di atas nampak bahwa begitu banyak hal yang dikenai pajak. Maka tidak mengherankan jika para pemimpin kaum Samin meramalkan bahwa rakyat se- gera akan harus membayar pajak untuk segala hal dalam hidup sehari-hari. Misalnya, memandikan ternak, mengubur orang meninggal, mengunjungi pasar, melewati jembatan dan jalan umum. Betapapun berlebihan ketakutan semacam ini, namun bagi kaum Samin tampak menyakitkan, karena ada begitu banyak macam pajak dan bea yang harus mereka tanggung. Inilah yang menjadi latar belakang boikot pajak yang dilakukan oleh gerakan Samin. Para pemimpinnya mempropagandakan bahwa mereka tidak wajib membayar pajak dan oleh karena itu mereka tidak dapat dihukum, jika menolak membayar pajak. Dengan propaganda seperti itu mereka banyak mendapat pengikut baru. ${ }^{33}$

Faktor ekonomis lain yang biasanya disebut sebagai penyebab perlawanan rakyat Samin adalah penutupan hutan jati oleh pemerintah. Daerah yang dihuni kaum Samin adalah daerah hutan jati yang terbaik di pulau Jawa. Pada tahun 1920, kira-kira $40 \%$ di kabupaten Blora adalah hutan jati. Melihat tingginya nilai kapital pada hutan jati yang ada di daerah itu, pemerintah ko-

${ }^{29}$ Ketika sapi-sapi Benggala didatangkan di Rembang pada tahun 1909-1911, petani harus membayar 5-20 sen. Bahkan petani yang tidak memiliki sapi juga harus membayar 5 sen. Demikian juga ketika sistem irigasi baru dibuat di Blora pada tahun 1912-1915, setiap petani ditarik 10 sen setiap bau. Akhimya, tebusan untuk mengganti kerja bakti untuk desa yang diterapkan pada tahun 1914 justru memberatkan para petani, karena pejabat-pejabat desa menciptakan bentuk-bentuk kerja bakti baru. (Lih. Benda/Castles (1969), hal. 219220; Sindhunata (1992), hal. 180-181).

${ }^{30} \mathrm{Bdk}$. Sindhunata (1992), hal 182.

${ }^{31 B d k . ~ I b i d ., ~ h a l . ~} 183$.

${ }^{32 B d k . ~ I b i d ~}$

${ }^{33}$ Bdk. lbid., hal. 183-184; Benda/Castles (1969), hal. 220. 
lonial sejak abad ke-19 membuat wilayah itu menjadi industri kehutanan. Kayu jati dari daerah itu pernah menjadi mutu terunggul di dunia dengan nama merek dagang Java-teak. Pemerintah mengadakan eksploitasi intensif di daerah itu dan menutup hutan bagi penduduk yang hidup di pinggiran hutan, seperti banyak kaum Samin. Dibentuklah Polisi Kehutanan untuk mengawasi hutan itu dan menghukum penduduk desa yang "mencuri" kayu dari hutan. ${ }^{34}$

Kaum Samin merasa bahwa hutan adalah warisan nenek moyang mereka seperti dirumuskan dalam ajaran mereka: "Lemah pada duwe, banyu pada duwe" (Tanah, air, dan hutan adalah milik semua"). Maka mereka mengadakan perlawanan, ketika hutan yang juga milik mereka, tiba-tiba dinyatakan tertutup bagi mereka yang jelas-jelas hidup di pinggiran hutan. Apalagi polisi kehutanan berbuat sewenang-wenang untuk menghukum yang dianggap sebagai "pencuri" kayu. Inilah yang memicu protes mereka melawan pemerintah. ${ }^{35}$

Di samping faktor-faktor ekonomis di atas, Korver menyebutkan faktor sosial dan politis. Yang dianggap sebagai faktor sosial oleh Korver adalah disintegrasi sosial yang dialami kaum Samin, ketika dominasi kolonial memasuki kehidupan sosial mereka dan merusak nilai-nilai dan ikatan-ikatan tradisional yang selama ini menjadi pilarpilar hidup mereka. Untuk menunjukkan adanya disentegrasi sosial tersebut, Korver mengutip Jasper yang menulis demikian, "dapat dikatakan secara umum bahwa pengikut Gerakan Samin bingung dan jengkel (pegel) menghadapi segala perubahan yang telah masuk ke dalam desa dan telah ditusukkan kepada penduduk desa ketika mereka merasa tidak ada lagi ikatan dengan nilai-nilai yang membentuk tatanan desa yang sama." ${ }^{\text {36 }}$

Sedangkan faktor politis yang memunculkan Gerakan Samin, menurut Korver, adalah ketidakberdayaan politis kaum Samin, dalam menghadapi birokrasi negara yang semakin menonjol. Politik etis telah mendatangkan banjir kriteria-kriteria, lembagalembaga, dan pajak baru yang meningkat di desa-desa. Hal ini biasanya menimbulkan perasaan tidak berdaya dan kecewa kepada penduduk lokal seperti yang direfleksikan oleh ramalan kaum Samin "bahwa pada suatu hari rakyat akan harus membayar bea untuk memandikan ternaknya, menguburkan orang meninggal, atau menggunakan jalan-jalan umum". ${ }^{37}$

\section{Agama Adam}

Dari uraian di atas nampak seolah-olah gerakan Samin "hanya" merupakan suatu gerakan perlawanan ekonomis belaka. Namun menurut banyak peneliti gerakan ini Victor T. King, Korver, dan Sindhunata, gerakan Samin muncul bukan hanya karena situasi ekonomis saja. ${ }^{38}$ Secara khusus Sindhunata mau memperlihatkan bahwa gerakan Samin merupakan suatu fenomena sosial yang kompleks, yang mendapatkan sumber dan daya kekuatan däri apa yang disebut sebagai Agama Adam. Berikut ini

\footnotetext{
${ }^{34}$ Bdk. Benda/Castles (1969), hal. 221-
} 223; Widiyanto (1983), hal. 62-64; Korver, "The Samin Movement and Millenarism (1976), hal. 256-257.

${ }^{35}$ Bdk. Ibid

${ }^{36}$ Bdk. Korver (1976), hal. 263.

${ }^{37} \mathrm{Bdk}$. Ibid. hal. 264.

${ }^{38}$ Victor T. King mengkritik analisis Benda dan Castles yang menonjolkan faktor ekonomis saja. Dia berusaha memperlihatkan adanyá faktor sosial dalam gerakan Samin (King, Victor, T., "The Samin Movement of North-Central Java" (1973), hal. 461 - 476). Sementara itu Korver secara eksplisit Memperlihatkan -adanya faktor-faktor sosial dan politis seperti telah diuraikan di atas. 
akan diikuti uraian Sindhunata yang mau memperlihatkan bahwa perhatian pada Agama Adam akan lebih banyak membantu orang untuk memahami gerakan Samin daripada pendekatan ekonomis (baik "ekonomis moral" muapun "ekonomis politis") yang biasanya digunakan untuk memahami gerakan protes kaum petani. ${ }^{39}$

Siapa yang dimaksud dengan Adam? Di mana dia? Menurut Sindhunata; kaum Samin akan menjawab pertanyaan itu demikian, "Saya Adam. Dia ada dalam diri saya." Jadi Adam diambil sebagai prinsip kemanusiaan yang universal. Artinya, setiap manusia adalah Adam dan dihidupi oleh Adam. Dalam Agama Adam setiap manusia itu sami (sederajat dan sama).

Dengan keyakinan itulah mereka menentang lembaga-lembaga sosial yang membuat manusia terbagi menjadi atasan dan bawahan. Protes kultural mereka ini terungkap dalam penolakan mereka terhadap penggunaan bahasa Jawa yang mengenai tingkatan basa ngoko (bahasa yang kasar) dan basa krama (bahasa yang sopan dan halus). Kaum Samin secara sadar berbicara dalam basa ngoko kepada setiap orang dengan tidak memandang kedudukannya dalam masyarakat seperti yang biasanya dilakukan oleh orang Jawa yang normal. Mereka menggunakan kata kowe juga untuk berbicara dengan pejabat pemerintah, termasuk bupati dan residen.

Tuntutan bahwa manusia itu sama dan sederajat, tidak hanya diungkapkan oleh kaum Samin melalui penggunaan bahasa, namun juga dalam tingkah laku dan tindakan mereka. Dalam pergaulan dengan para pegawai kolonial mereka tidak lagi memperhatikan aturan sopan-santun yang biasa. Mereka memperlakukan orang Belanda seperti teman yang sederajat. Demikianlah dilaporkan oleh J.E. Jasper, Asisten Residen Tuban bahwa Pódirono, seorang Samin dari Kolpoduwur, Blora secara sengaja me- letakkan kakinya di atas meja ketika Jasper mengunjunginya.

Selanjutnya Sindhunata menjelaskan ajaran Agama Adam yang berbunyi "Lemah pada duwe, banyu pada duwe, kayu pada duwe". Artinya, tanah air, dan kayu (hutan) adalah milik semua manusia dan setiap manusia memiliki hak yang sama atas kekayaan alam itu. Pengertian ini membuat kaum Samin dikategorikan sebagai "Komunis" dalam beberapa berita dan analisis orang Belanda. Suatu bentuk "komunisme" ini merupakan aspek yang lain dari dunia egaliter kaum Samin.

Dunia orang Samin sangat terbebas, yakni "hanya" desa mereka. Apa yang terjadi di luar itu, mereka tidak tertarik. Mereka menolak otoritas pemerintah, karena otoritas bagi mereka hanyalah kekuasaan atas rumah, keluarga, warisan, dan tanah. Ajaran Agama Adam memberikan penghargaan yang tinggi pada kesatuan sosial yang kecil seperti rumah tangga. Ajaran itu menolak otoritas dan birokrasi regional dan nasional yang modern dan mengidealkan komunitas desa yang terisolasi, otonom, dan mampu mencukupi kebutuhannya sendiri. Inilah yang membuat gerakan orang Samin dinilai sebagai gerakan "eskapis". Menurut Sindhunata, "eskapisme" kaum Samin dapat lebih jelas dipahami dengan menggunakan pendekatan "ekonomi moral" ("moral economy). ${ }^{40}$

Menurut penganut "ekonomi moral", protes kaum tani merupakan reaksi defensif terhadap kapitalisme dan usaha untuk menegakkan kembali struktur-struktur pra kapitalis yang dulu pernah menjamin keadaan

${ }^{39}$ Bagian ini terutama akan mengacu pada: Sindhunata (1992), hal. 187-206.

40Tiga tokoh yang menggunakan pendekatan "ekonomi moral" adalah James Scott, The Moral Economy of the Peasant. Rebel- 
baik mereka. Dibalik pandangan ini terdapat premis moral bahwa lembaga-lembaga tradisional, pra-kapitalis lebih baik dan cocok bagi kebaikan petani daripada lembagalembaga sosial modern pada masa kapitalis.

Dalam pendekatan "ekonomi moral" ini etika subsistensi memegang peranan penting. Kapastian subsisterisi ekonomis merupakan kriteria menetukan bagi kaum tani. Artinya, kaum tani takut akan resiko. Maka yang penting bagi mereka bukanlah usaha untuk memaksimalkan laba yag bisa diharapkan, melainkan untuk tidak jatuh ke bawah tingkat subsistensi. Institusi yang sentral bagi kaum tani untuk menciptakan kepastian subsistensi ini dalam masyarakat pra-kapitalis adalah desa. Desa juga dianggap sebagai jaminan institusional agar prinsip kepastian ini bisa berfungsi secara optimal. Maka pengikut ekonomi moral memiliki bayangan yang ideal (mungkin terlalu optimis) terhadap desa pra-kapitalis yang dianggap sebagai lembaga yang memungkinkan pelaksanaan etika subsistensi. Di dalam juga termasuk sistem patron-klien yang mereka anggap dapat berfungsi baik dalam desa pra-kapitalis itu dan dapat mendahulukan dan menjaga hak-hak subsisten kaum tani yang fundamental.

Dengan munculnya kapitalisme di daerah-daerah koloni, maka semua institusi pra-kapitalis tersebut porak-poranda. Kaum tani harus hidup tanpa kepastian dan perlindungan dari lembaga-lembaga tradisional mereka. Gerakan Samin juga muncul ketika kapitalisme kolonial makin hari makin merambah desa-desa di Jawa. Walaupun politik etis memiliki tujuan yang baik, yakni untuk mengembangkan dan memodernisasi desa-desa Jawa, namun sekaligus merupakan sarana untuk meluaskan kekuasan modal swasta.

Daerah-daerah kaum Samin juga secara intensif terkena perembesan kapitalis- me kolonial ini. Sadar atau tidak sadar, kaum Samin mengalami bahwa kapitalisme mengakibatkan likuidasi semua lembagalembaga kepastian tradisional bagi desa mereka. Dalam hal ini Agama Adam bisa diinterpretasikan sebagai suatu reaksi defensif melawan kapitalisme kolonial dalam pengertian "ekonomi moral": Di balik citacita kaum Samin untuk menolak otoritas pemerintah dan membangun kembali suatu "komunisme" desa dengan "kesederhanaan pedusunan" terdapat keyakinan yang tidak mutlak diartikulasikan, bahwa "keadaan prakapitalis" dulu lebih baik daripada yang keadaan "sekarang". Maka harus ditegakkan kembali:

Akan tetapi interpretasi ekapisme kaum Samin dengan pendekatan "ekonomi moral" di atas, menurut Sindhunata, menjadi tidak meyakinkan berhadapan dengan ajaran dasar Agama Adam selanjutnya yang berbunyi, "Wong sikep weruh theke dewe" (Orang sikep tahu apa yang menjadi miliknya"). Bertolak belakang dengan sebutan "komunisme awal" yang diberikan pada Gerakan Samin, ajaran ini justru menunjukkan "egoisme" kaum Samin. Sesuai dengan ajaran dasar ini, kaum Samin memang menolak untuk ikut serta dalam kegiatan bersama di desa mereka. Hanya milik mereka (tanah, isteri, dan anak-anak) yang harus dipelihara. Itulah sebabnya mereka tidak mau bekerja untuk yang lain dan di tanah yang bukan menjadi milik mereka.

Ajaran dasar yang kedua ini tidak dapat dijelaskan hanya sebagai reaksi "defensif" melawan perembesan politik etis di dalam komunitas desa yang akhirnya meng-

lion and Substance in Southeast Asia (London, 1976), e. Wolf, Peasant Wars of the Twetieth Century (London, 1969), dan J. Mignal, Peasant, Polititc, and Revolution. Pressures toward Political and Social in the Third World (Prineton, 1974). 
eksploitasi rakyat. Ajaran ini merupakan credo Agama Adam. Isinya mewarisi semangat individualisme. Dengan demikian ajaran dasar ini tidak sesuai dengan teori "ekonomi moral". Jiwa individualistisnya ini lebih cocok dengan kriteria para pengkritik "ekonomi moral", yakni para penganut teori "ekonomi politis".

Sementara "ekonomi moral" bertitik tolak dari komunitas desa yang ideal, yang baik bagi individu, "ekonomi politis" berangkat dari kepentingan pribadi para petani. Pendekatan "ekonomi politis" tidak membayangkan gambaran suatu institusi desa yang ideal dan mencukupi. Desa dipandang secara realistis sebagai institusi sosial yang di dalamnya mungkin saja terjadi konflik antar individu atau antara individu dengan kelompok. Para petani tidak hanya bercitacita untuk mempertahankan tuntutan subsistennya, namun lebih dari itu untuk meningkatkan tingkat subsistennya, juga jika mereka harus menghadapi resiko. Mereka juga mampu membuat investasi. Inilah yang biasanya disebut sebagai "petani rasional". Artinya, petani yang dapat mengembangkan rumah tangga dan keluarganya dalam pespektif masa depan. Rasionalitas ini berkaitan dengan kepentingan individu dan dapat dibedakan dengan rasionalitas yang berkaitan dengan seluruh desa.

Analisis "ekonomi politis" ini menekankan kemungkinan bagi seorang individu untuk memutuskan keterlibatan dalam barangbarang dan proyek-proyek bersama berdasarkan keuntungan pribadi. Secara terbuka kaum Samin juga menunjukkan suatu individualisme yang keras seperti yang secara ringkas dirumuskan dalam credo Agama Adam. Ajaran dasar ini merupakan versi kaum Samin dari apa yang oleh "ekonomi politis" dalam analisisnya disebut sebagai individualisme petani.

Dari uraian di atas terlihat bahwa Agama Adam menunjukkan suatu fenomena yang kompleks yang bisa menyatukan ide yang bertolak belakang seperti "komunisme awal" dan "individualisme". Hal ini juga tercermin dalam interpretasi yang bertolak belakang dari "ekonomi moral" dan "ekonomi politis". Menurut Sindhunata, pertentangan keduanya memberi petunjuk bahwa suatu interpretasi sosio-ekonomis murni tidak memadai untuk memahami Gerakan Samin yang multi-dimensional. Fenomena keseluruhan dari gerakan ini hanya dapat dilihat, jika kita memahaminya sebagai suatu gerakan yang memiliki falsafah hidup religius seperti nampak dalam Agama Adam.

Sindhunata menunjukkan hal ini misalnya dalam pemahaman tentang sikep yang memiliki peranan penting dalam Agama Adam. Biasanya sikep dipahami sebagai pengertian sosio-ekonomis dan berarti pemilik tanah wajib membayar pajak. Bagi kaum Samin sikep berarti lebih dari itu. Sikep merupakan suatu pengertian normatif yang berisi suatu jenis kondeks tindakan bagi kelompok petani. Sikep tidak hanya dimaksudkan sebagai petani dalam arti suatu pekerjaan di antara yang lainnya suatu jenis "panggilan". Tanggung jawab sendiri bagi kelompok sikep dengan hak dan kewajiban mereka harus dihidupi dan diterima sebagai nasib atau takdir.

Secara harafiah sikep dapat berarti "memeluk seorang perempuan". Itulah sebabnya kaum Samin menyebut istrinya sebagai sikep dan dirinya sendiri sebagai wong sikep (orang yang memeluk). Kedua pengertian itu bagi mereka memiliki suatu konotasi seksual yang jelas. Jika dalam suatu kalimat kaum Samin berbunyi: "wong sikep tak kenal pajak atau kerja bakti", maka ungkapan ini sekaligus merupakan sindiran akan satu-satunya "penyerahan dan pengabdian" yang mereka selalu siap, yakni "pelayanan malam" untuk isterinya.

Bagi kaum Samin isteri dan keluarga harus ditempatkan di atas segalanya. Aga- 
ma Adam menjadi perlindungan bagi apa yang harus dijaga di atas segalanya, yakni keluarga mereka. Namun keluarga juga menjadi kubu pertahanan melawan setiap otoritas lain yang mau menguasai dan menundukkan keluarga petani. Dalam kaitan ini, menurut Sindhunata, sangat berharga untuk mengerti arti kata omah bagi mereka. Dalam bahwa Jawa yang biasa omah berarti "rumah" dalam pengertian material dan fungsional. Untuk pengertian seperti kaum Samin menggunakan kata pondokan. Sebaliknya, omah bagi mereka tidak hanya berarti bangunan material, melainkan juga ruang yang memberikan perlindungan dan kepastian. Di dalam ruang itu kehidupan pribadi dan keluarga mereka dijaga dan dilindungi. Itulah sebabnya kaum Samin tidak mengakui otoritas yang lain di luar isteri mereka. Bukan pemerintah yang harus menerima "semua pajak", "semua pengabdian", dan "segala ketaatan" mereka, melainkan isteri mereka.

Motif-motif tertentu dalam Agama Adam seperti namipak dalam ajaran-ajaran dasar di atas, menurut Sindhunata, adalah dasar dan tanah bagi kaum Samin untuk hidup dan bekerja sebagai petani. Dari motif-motif tersebutlah.mereka hidup dan mengalami kesuburan alam yang tidak dapat mereka ciptakan sendiri. Mereka meletakkan kekinian kekuatan dan kekuasaan dalam motif-motif itu. Mereka mengalami kesuburan alam itu lebih sebagai kekuasaan adi-kodrati dan magis. Mereka memuja dan bahkan "mengillahikan" kesuburan alam ini. "Allah" semacam itu tidak dapat dicapai. Meskipun begitu dia memanifestasikan dirinya dalam semua yang bisa diartikan sebagai kesuburan seperti kehidupan seksual lakilaki dan perempuan. Dari sinilah seksualitas manusia memperoleh dimensi "religius" dan "magis"-nya. Pandangan ini merupakan dasár bagi Agama Adam.
Selanjutnya, menurut Sindhunata, pandangan kaum Samin ini dikaitkan dengan pemujaan Lingga-Yoni dalam budaya Hindu yang diyakini oleh orang Jawa (termasuk kaum Samin). Melalui pengaruh budaya ini kehidupan seksual menjadi simbol bagi kesatuan antara Yang Illahi dengan manusia. Manusia mencita-citakan dan memohon kesatuan itu. Di dalam kesatuan itu manusia dibebaskan dari segala yang menghalangi dan membusukkan eksistensinya sebagai manusia. Maka dia dapat menemukan dirinya dalam keadaan bebas. Dalam kebebasan inilah keberadaan manusia mencapai kepenuhannya.

Kebebasan adalah hakikat dari Agama Adam. Menurut Sindhunata, kaum Samin mempertahankan dan menjaganya sebagai credo religius mereka. Dengan bertitik tolak darinya mereka hidup dan mendemonstrasikan kebebasan mereka itu dalam kehjdupan sehari-hari. Ini adalah sumber batiniyah, asal dari tindakan dan perlawanan mereka dalam kehidupan sehari-hari. Kebebasan batiniah ini merupakan "kriteria bagi kemungkinan" bahwa mereka dapat mempertahankan secara kokoh perlawanan mereka.

\section{Penutup}

Yang paling mengagumkan dari Gerakan Samin adalah perlawanan mereka yang terus menerus dan tanpa kekerasan. Gerakan ini dalam arti tertentu bisa dipahami sebagai "dokumentasi"historis dari perlawanan kaum tani dalam hidup seharihari. Gerakan ini merupakan suatu pemadatan yang masif dari perlawanan seharihari yang dalam gerakan kaum tani lainnya hanya dapat dikenali secara sporadis.

Perlawanan sehari-hari ini bagi pemahaman protes petani memiliki arti yang besar, karena perlawanan semacam ini merelatifkan ciri "tiba-tiba" dari revolusi kaum 
tani atau Ratu Adilyang milenaris. Dengan latar belakang ini revolusi kaum tani yang "tiba-tiba" dan dengan kekerasan hanyalah suatu momen dari seluruh kehidupan petani pada umumnya. Bahkan sekaligus revolusi seperti itu merupakan keadaan darurat yang biasanya diakhiri dengan kekalahan. Namun kekalahan ini sedikitpun tidak membuat rapuh perlawanan petani pada masa "normal". Secara diam-diam kaum tani sebenarnya lebih banyak melakukan perlawanan sehari-hari yang tidak spektakuler sehingga biasanya juga tidak didokumentasikan.

Dalam Gerakan Samin menjadi jelas bahwa perlawanan sehari-hari ini meliputi banyak unsur. Jika kita menjelaskannya hanya secara ekonomis, maka kita sampai pada pemahaman yang saling berlawanan dan membatasi, seperti pertentangan antara "Komunisme desa" dengan "egoisme". Kedua aspek ini sungguh-sungguh ada pada kaum Samin. Namun keduanya tidak bertentangan satu sama lain, melainkan hanya dapat dipahami secara benar dalam kerangka agama atau falsafah hidup. Gerakan Samin seperti tampak dalam Agama Adam.

Perlawanan kaum tani dalam hidup sehari-hari tidak dapat dilepaskan dari kehidupan mereka secara keseluruhan. Bagi kaum Samin hal ini berpusat pada Agama Adam yang bukan merupakan doktrin yang abstrak atau suatu ibadat yang khusus kepada Yang illahi yang terlepas dari kehidupan sehari-hari. Maka yang disebut dengan Agama Adam sebenarnya adalah kepenuhan hidup yang bagi kaum Samin merupakan sesuatu, yang jelas dan konkret seperti kehidupan mereka sendiri.

Agama Adam merupakan sumber bagi tindakan dan perlawanan tanpa kekerasan dari kaum Samin. Tanpa Sumber ini akan sulit dipahami, bagaimana kaum Samin sebagaimana wong cilik memiliki keberanian yang besar untuk melawan kekuasan ne- gara dan menolaknya. Hanya dengan memahami sumber batiniah inilah kita dapat mengerti, mengapa mereka mampu melakukan protes yang unik dan berani bagi orang Jawa biasa juga sulit dipahami. Betapapun aneh dan naifnya protes kaum Samin dalam masing-masing tingkah lakunya; hal ini sebenarnya hanya merupakan ungkapan dari harapan terdalam mereka akan kebebasan sepenuhnya sebagai manusia dalam kehidupan mereka.

\section{Daftar Pustaka}

Benda, Harry J/Castles, Lance, "The Samin Movement", dalam: Bijdragen tot de tall, Land, end Volkenkunde, Koninklijk Institut voor Tall-, Land-, en Volkenkunde (disingkat: $\mathrm{BKI}$ ), Vol. 125, 1969, hal. 207-240.

King. Victor T., "Some Observation on the Samin Movement of North-Central Java. Suggestions for the Theoretical Analysis of the Dynamics of Rural Unrest", dalam: BKI, Vol. 129, 1973, hal. 457-481.

King. Victor T., "Status, Economic Determinism and Monocasuality. More on the Samin", dalam: $B K I$, Vol. 133, 1977, hl. 350-354.

Korver; A.P.E., The Samin Movement and Milenarism", dalam: BKI, Vol. 132, 1976, hal. 249-268.

Sadi Hutomo, Suripan, "Bahasa dan Sastra Lisan Orang Samin", dalam: Basis, 1983, hal. 31-40.

Sadi Hutomo, Suripan, "Samin Surontiko dan Ajaran-ajarannya", dalam: Basis, 1985, hal. 2-15-0, 56-65.

Shiraisi, Takashi, "Dangir's Testimony: Saminism Reconsidered", dalam: Indonesia, 1990, hal. 95-120.

Shiraisi, Takashi, Zaman Bergerak. Radikalisme Rakyat di Jawa 1912-1926, Jakarta: Grafiti, 1997. 
Topik: Gerakan Samin: Perlawanan Rakyat Tanpa Kekerasan, A. Widyarsono

Sindhunata, "Die Samin-Bewegung" dalam: Widiyanto, P., "Samin Surontiko dan KonSindhunata, Hoffen auf den Ratu-Adil, Hambur: Kovac, 1992, hal. 175-208. teknya", dalam: Prisma. No 8 Agustus 1983, hal. 59-67.

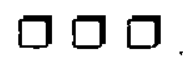

